\title{
ATTITUDES AND KNOWLEDGE TOWARDS REPRODUCTIVE HEALTH AND SEXUAL MATURATION AMONG SECONDARY SCHOOL STUDENTS IN VOJVODINA
}

\author{
Tatjana Pavlica, Snježana Janjić-Gajšin, Vašaš Čila, Sabo Gabor \\ University of Novi Sad, Faculty of Sciences, Department of Biology and Ecology, \\ Laboratory for Human Biology, Novi Sad, Serbia
}

\begin{abstract}
Summary
Adolescence is a period in which young people are exposed to various physiological disorders, diseases and social consequences of risky behavior. Sudden changes in society leading to increased poverty, changes of values and increased crime rate can all cause risky behavior among young people. The aim of the study was to establish the attitudes and knowledge of secondary school students in Vojvodina related to the human body, physiological processes, sexual maturation and reproductive health. The study also focused on students' attitudes towards sexual intercourse and to what extent the topics related to reproductive health are present in the school curriculum. In this investigation we used data obtained in a recent research on second, third and fourth-year secondary students in some municipalities of Vojvodina in 2012 and 2013. The students were examined in the municipalities of Ruma, Senta, Čoka, Kanjiža and Subotica. We applied the method of survey. The questions were both open and closed, and divided into four groups: knowledge on the human body and sexual organs, information on sexual maturation and reproductive health, attitudes towards sexual intercourse and students' views on the content of reproductive health issues in the curriculum. The adolescents do not know enough about the human body and the basic physiological processes and show insufficient awareness of the importance of using contraception to preserve their reproductive health. Most of the students express a positive opinion of introducing a special subject into the curriculum that would deal with issues related to reproductive health. The obtained data are consistent with other previous studies in Serbia, suggesting that nothing has changed in this segment of our medical culture. The results suggest that young people need sexual education that corresponds to their age and needs, in order to be able to increase their knowledge and improve skills that can help them maintain their health.
\end{abstract}

Key words: Adolescents, reproductive health, sexual maturation, Vojvodina.

\section{Introduction}

By the definition of the World Health Organization adolescence is a stage of postnatal life, which covers the period from 10 to 19 years of age (www.who.int/maternal_child_ adolescent/topics/adolescence/dev/en). It is estimated that this population group currently includes 1.2 billion individuals and as such is the largest population group of adolescents in the history of mankind (UNICEF, 2012). Adolescence is a period of preparation for adulthood, which in addition to physical and sexual development is characterized by knowledge improvement, social and identity development, as well as the development of skills needed for economical independence and the world of adults. Young people create a very heterogeneous group as they are in various stages of development, live in different conditions and have different needs. They also differ considering the level of knowledge and skills needed to help them preserve their health. Adolescents are generally considered to be the 
healthiest population category. However, this is a period in which young people are also exposed to various physiological disorders, diseases and social consequences of risky behavior. Sudden changes in society leading to increased poverty, migration, changes of values and increased crime rate can all cause risky behavior among young people. This usually includes psychoactive substance abuse, unsafe sex and the risk of getting sexually transmitted diseases (UNICEF, 1999).

Serbia and other countries in transition are now facing a number of socio-economic and political changes that have a great impact on the lives and health of young people. Unemployment, long period of economic dependence, abuse of alcohol, tobacco and drugs as well as increasing epidemics of sexually transmitted diseases are all very common phenomena today. Previous studies in Serbia have indicated that risky behavior is very common among young people (Korać-Mandić and Novaković, 2008). They become sexually active due to curiosity, physical attraction or pressure from a partner, and only a small percentage of them use some form of contraception. Final Report: Initiative for Youth Reproductive Health (Korać-Mandić and Novaković, 2008) indicates that in Serbia 16000 adolescent pregnancies are registered every year. More than $90 \%$ of these pregnancies are unplanned and unwanted and more than $90 \%$ end in abortion. Infertility is the most serious consequence of induced abortions and the incidence of secondary infertility after induced abortions in women who have not previously given birth in Serbia is around 14.4\% (Korać-Mandić and Novaković, 2008). Also, the data indicate that 20-30\% of adolescents in Serbia have at least one sexually transmitted infection. The studies conducted during the past decades have pointed out that adolescents become sexually active at earlier age (Rašević, 2006; Sedlecki, 2001).

Adolescent behavior and attitudes are under the influence of both biological, social, and socio-economic factors. These factors are mutually interdependent and indirectly influence the behavior and decisions of young people (Kapamadžija, 2002; Stanković, 2007; Stefanović-Stanojević, 2011). In order to make positive decisions considering their health, young people need to have a certain level of knowledge, physical maturity and self-esteem. Young people are often ill-informed about the physiological processes and structure of their bodies and completely unprepared to deal with the changes occurring during adolescence. They often receive contradictory information. Their parents and teachers inform them of possible consequences of risky behavior and early sexual intercourse, while media on the other side sends the opposite information indicating that such behavior is perfectly normal at their age (www.who.int/maternal_child_adolescent/topics/adolescence/dev/en).

The aim of the study was to establish the attitudes and knowledge of secondary school students in Vojvodina related to the human body, physiological processes, sexual maturation and reproductive health. The study also focused on students' attitudes towards sexual intercourse and to what extent topics related to reproductive health are present in the school curriculum.

\section{Methods}

This investigation used data obtained in a recent research on second, third and fourth year secondary school students in some municipalities of Vojvodina in 2012 and 2013. The students were examined in the municipalities of Ruma, Senta, Čoka, Kanjiža and Subotica. The results presented in this paper are parts of master theses (Janjić-Gajšin, 2012; Vašaš, 2013; Sabo, 2013). Table 1 shows the total number of students in certain places.

We applied the method of survey. Before filling in the survey lists, the students were informed of the purpose and the aim of the questionnaire. The questions were both open and closed, and divided into four groups. The first group - knowledge on the human body and sexual organs, contained eight open questions where students wrote their answers. The second segment - information on sexual maturation and reproductive health - included five open-ended questions. 
The third group of questions - attitudes towards sexual intercourse- had 6 closed questions, where respondents chose one or multiple answers. The fourth group - Students' views on the content of reproductive health issues in the curriculum- included four closed questions.

Table 1. The total of respondents in individual surveys

Tabela 1. Ukupan broj ispitanih učenika u pojedinim istraživanjima

\begin{tabular}{|c|c|c|c|c|c|}
\hline \multirow[t]{2}{*}{ Region } & \multirow[t]{2}{*}{ School } & \multicolumn{3}{|c|}{$\begin{array}{l}\text { The total of } \\
\text { respondents }\end{array}$} & \multirow[t]{2}{*}{ Source } \\
\hline & & Boys & Girls & Total & \\
\hline Ruma & $\begin{array}{l}\text { "Stevan Petrović Brile" "Milenko Brzak Uča" } \\
\text { "Stevan Puzić" }\end{array}$ & 161 & 129 & 290 & $\begin{array}{l}\text { Janjić-Gajšin, } \\
2012\end{array}$ \\
\hline $\begin{array}{l}\text { Senta, Čoka, } \\
\text { Kanjiža }\end{array}$ & $\begin{array}{l}\text { "Gymnasium Senta" } \\
\text { "Gymnasium with Student's Dormitory for } \\
\text { gifted students Bolyai" } \\
\text { "Medical High School" } \\
\text { Agricultural and Technical High School Center } \\
\text { Besedeš Jožef } \\
\text { "Hemijsko -Food High School" }\end{array}$ & 228 & 355 & 583 & Vašaš, 2013 \\
\hline Subotica & $\begin{array}{l}\text { Gymnasium" Svetozar Marković" } \\
\text { Gymnasium"Deže Kostolanji" } \\
\text { "Medical High School” }\end{array}$ & 151 & 193 & 344 & Sabo, 2013 \\
\hline
\end{tabular}

Data processing was performed by Microsoft Excel program, and the research results were presented in tables. All the data were acquired with the written consent of the Academic Council of Faculty of Sciences and Department of Biology and Ecology in Novi Sad, and also with a consent of the headmaster of the school where the research took place. The subjects voluntarily participated in the investigation. All applicable institutional regulations concerning the ethical use of human volunteers were followed during this research.

\section{Results}

Table 2 presents the results of student responses to questions on their awareness of the human body and genitals. All the responses of students are shown and the percentages presented. It is observed that in the first question, in which students had to number the parts of the male reproductive system, the highest percentage of respondents (43.74\%) can name just two organs. Approximately $20 \%$ of students believe that only penis is a part of the reproductive system, whereas a very small percentage of students can number several parts of the reproductive system. Approximately $7.5 \%$ of the students do not know the answer to this question. The majority of students $(62.44 \%)$ know that sperm is a male gamete, however, even $37.57 \%$ of them choose an incorrect answer. The similar results are observed regarding the female reproductive system. Only a small percentage of respondents can name all parts of the female reproductive system, while $77.36 \%$ of them can state the exact name of female gamete. The question "When do the fertile days occur" has about $64 \%$ of the right answers. However, it is important to notice that the number of those who give an incorrect answer to this question is rather high - 20.42\%. The correct answer to the question "how does a twin pregnancy occur" is provided by $42.36 \%$ students, while more than a half of the respondents do not know the answer or give incorrect answers. As for the definition of ovulation, $40.90 \%$ of high school students answered correctly, and a significant percentage of students $(49.17 \%)$ believe that menstruation is the process of releasing an egg from the ovary into the fallopian tube. 
Table 2. Students' knowledge on the human body and sexual organs

Tabela 2. Informisanost učenika o ljudskom telu i polnim organima

\begin{tabular}{|c|c|c|c|}
\hline & Questions & Answers & Total \% \\
\hline \multirow[t]{10}{*}{1.} & \multirow{10}{*}{$\begin{array}{l}\text { Name the parts of male } \\
\text { reproductive system }\end{array}$} & Penis & 19.73 \\
\hline & & Testes & 1.20 \\
\hline & & Testes, penis & 43.74 \\
\hline & & Testes, penis, prostate & 6.35 \\
\hline & & Testes, penis, epididymis & 0.17 \\
\hline & & Testes, prostate, seminal vesicle, ductus deferens, penis & 8.58 \\
\hline & & Testes, epididymis, seminal vesicle, ductus deferens, penis & 4.12 \\
\hline & & $\begin{array}{l}\text { Testes, epididymis, seminal vesicle, ductus deferens, } \\
\text { prostate, penis }\end{array}$ & 5.15 \\
\hline & & $\begin{array}{l}\text { Testes, epididymis, skrotum, ductus deferens, prostate, } \\
\text { urethra, penis }\end{array}$ & 3.43 \\
\hline & & I don't know & 7.55 \\
\hline \multirow[t]{5}{*}{2.} & \multirow[t]{5}{*}{ Name the male sex cell } & Spermatozoid & 62.44 \\
\hline & & Sperm & 17.84 \\
\hline & & Testis & 2.40 \\
\hline & & Testosterone & 3.09 \\
\hline & & I don't know & 14.24 \\
\hline \multirow[t]{13}{*}{3.} & \multirow{13}{*}{$\begin{array}{l}\text { Name the parts of female } \\
\text { reproductive system }\end{array}$} & Vagina & 23.33 \\
\hline & & Ovaries & 1.37 \\
\hline & & Vagina, ovaries & 6.00 \\
\hline & & Vagina, clitoris & 0.69 \\
\hline & & Vagina, breasts & 1.72 \\
\hline & & Vagina, uterus, ovaries & 16.64 \\
\hline & & Vagina, uterus, fallopian tube, ovaries & 14.58 \\
\hline & & Labia, vagina, uterus, ovaries & 2.57 \\
\hline & & Labia, vagina, uterus, fallopian tube, ovaries & 7.38 \\
\hline & & Clitoris, vagina, uterus, fallopian tube, ovaries & 3.60 \\
\hline & & Labia, clitoris, vagina, uterus, fallopian tube, ovaries & 6.17 \\
\hline & & Labia, clitoris, vagina, cervix, uterus, fallopian tube, ovaries & 6.00 \\
\hline & & I don't know & 9.95 \\
\hline \multirow[t]{4}{*}{4.} & \multirow[t]{4}{*}{ Name the female sex cell } & Egg & 77.36 \\
\hline & & Ovary & 3.43 \\
\hline & & Estrogen, progesterone & 2.40 \\
\hline & & I don’t know & 16.81 \\
\hline \multirow[t]{7}{*}{5.} & \multirow{7}{*}{$\begin{array}{l}\text { When do fertile days } \\
\text { occur? }\end{array}$} & Mid-menstrual cycle $12^{\text {th }}-16^{\text {th }}$ day & 43.05 \\
\hline & & $14^{\text {th }}$ day & 21.44 \\
\hline & & from $7^{\text {th }}$ to $14^{\text {th }}$ day & 0.86 \\
\hline & & from $5^{\text {th }}$ to $7^{\text {th }}$ day after menstruation & 9.95 \\
\hline & & 5 days prior menstruation & 2.06 \\
\hline & & The first 4 days & 2.23 \\
\hline & & I don't know & 20.41 \\
\hline \multirow[t]{7}{*}{6.} & \multirow{7}{*}{$\begin{array}{l}\text { How does twin } \\
\text { pregnancy occur? }\end{array}$} & Fertilization of 2 eggs or the splitting of a fertilized egg & 16.12 \\
\hline & & Fertilization of 2 or more eggs & 15.78 \\
\hline & & Splitting of the fertilized egg & 10.46 \\
\hline & & Fertilization of an egg with two spermatozoids & 6.00 \\
\hline & & Fertilization of 2 eggs or 1 egg fertilized by 2 spermatozoids & 2.92 \\
\hline & & Family predisposition & 1.37 \\
\hline & & I don't know & 47.34 \\
\hline \multirow[t]{4}{*}{7.} & \multirow{4}{*}{$\begin{array}{l}\text { What is the name of the } \\
\text { process of releasing an } \\
\text { egg from the ovary into } \\
\text { the fallopian tube? }\end{array}$} & Ovulation & 40.90 \\
\hline & & Menstruation & 49.17 \\
\hline & & Fertilization & 1.65 \\
\hline & & I don't know & 8.06 \\
\hline
\end{tabular}


The students' responses to the second set of questions, considering their knowledge on sexual maturation and reproductive health, are presented in Table 3. The majority of students (48.89\%) marked the Internet as a primary source of information. The second source of information is from friends (33.10\%), while $18.35 \%$ of students chose parents and $12.86 \%$ of them chose the teacher of biology is an important source of information on these issues. To a lesser extent, reproductive health information is obtained through television and magazines, while only a small number of respondents are informed by their teacher, educator or psychologist. The highest percentage of students think that parents do not talk to them enough about the issues related to reproductive health, or that they do that sometimes. The highest percentage of students openly talk about sex with their friends $(49.06 \%)$ or partner $(42.54 \%)$, while a smaller percentage of them talk to their parents $(11.84 \%)$ or siblings $(6 \%)$. The respondents state that they lack the most information on sexually transmitted diseases

Table 3. Students' knowledge on sexual maturation and reproductive health Tabela 3. Informisanost učenika o polnom sazrevanju i reproduktivnom zdravlju

\begin{tabular}{|c|c|c|}
\hline No. Questions & Answers & Total $\%$ \\
\hline \multirow{8}{*}{$\begin{array}{l}\text { 1. In what way do you obtain information on } \\
\text { reproductive health? }\end{array}$} & Magazines & 6.35 \\
\hline & The Internet & 48.89 \\
\hline & Television & 8.23 \\
\hline & Pedagogist/psychologist & 1.03 \\
\hline & Head teacher & 2.40 \\
\hline & Parents & 18.35 \\
\hline & Friends & 33.10 \\
\hline & Biology teacher & 12.86 \\
\hline \multirow{3}{*}{$\begin{array}{l}\text { 2. Do you discuss sexuality and reproductive health } \\
\text { topics with your parents? }\end{array}$} & Yes & 23.50 \\
\hline & No & 39.45 \\
\hline & Sometimes & 37.05 \\
\hline \multirow[t]{5}{*}{ 3. With whom can you openly talk about sex? } & Friend & 49.06 \\
\hline & Partner & 42.54 \\
\hline & Parent & 11.84 \\
\hline & Brother/Sister & 6.35 \\
\hline & No one & 6.17 \\
\hline \multirow{4}{*}{$\begin{array}{l}\text { 4. On what topics would you like to obtain more } \\
\text { information? }\end{array}$} & Contraception & 19.04 \\
\hline & Sexually transmitted diseases & 38.59 \\
\hline & Abortion & 28.13 \\
\hline & All above & 14.24 \\
\hline \multirow{5}{*}{$\begin{array}{l}\text { 5. In what way should youth counseling be } \\
\text { organized? }\end{array}$} & Workshops & 28.47 \\
\hline & School facilities & 33.96 \\
\hline & Young people as counselors & 28.47 \\
\hline & Via the telephone & 8.40 \\
\hline & Internet forums & 0.69 \\
\hline \multirow[t]{8}{*}{ 6. Which sexual diseases can you name? } & AIDS & 97.07 \\
\hline & Syphilis & 44.74 \\
\hline & Tripper & 25.92 \\
\hline & Gonorrhea & 13.69 \\
\hline & Herpes & 6.06 \\
\hline & Hepatitis & 10.76 \\
\hline & Condyloma & 2.93 \\
\hline & Chlamydia & 6.85 \\
\hline \multirow{4}{*}{$\begin{array}{l}\text { 7. Name possible methods of protection from } \\
\text { sexually transmitted diseases }\end{array}$} & Condom & 77.95 \\
\hline & Abstinence & 5.37 \\
\hline & Steady partner and medical check ups & 1.61 \\
\hline & Incorrect answers & 33.37 \\
\hline
\end{tabular}


(38.59\%), abortion (28.13\%) and contraception (19.04\%), while some students report that they would like more information on all of these issues. As an essential condition for organizing youth counseling, students in the highest percentage (33.96\%) state that it should be organized within school. The same percentage of them $(28.47 \%)$ think that the work should be organized in groups and with young counselors. The possibility to obtain the information by telephone is appealing to $8 \%$ of students, while a very small percentage believe that counseling should be organized through online forums. As for the listing of venereal diseases, the majority of respondents are able to specify only one sexually transmitted disease. In doing so, students often cite AIDS (97.07\%), syphilis (44.74\%), tripper (25.92\%), or gonorrhea (13.69\%) and hepatitis $(10.76 \%)$. Of the total number of students who are able to specify a method of protection against sexually transmitted diseases, the highest percentage mention condom $(77.95 \%)$ and a smaller percentage abstinence (5.37\%). Partially correct answers, such as a steady partner and medical examination are chosen by $1.61 \%$ of students, while $33.37 \%$ of them wrote incorrect answers.

Table 4 shows the responses of students referring to their attitudes to sexual intercourse. In this group of questions, the analysis included the respondents' sex, as we examined differences in responses between boys and girls. It can be observed that for the majority of young people (65\%), love is very important when engaging in sexual activity. This refers more to girls than boys. Young men are more likely to believe that love is not needed, and about $10 \%$ of the students have no opinion on the matter. When asked if at the beginning of sexual development they felt mature enough to engage in sexual intercourse, there are also differences in the boys and girls' responses. A higher percentage of boys (52\%) than girls (25\%) say they feel mature enough to begin with sexual activity. However, at the question "Have you had sexual experience," a higher percentage of girls (60\%) than boys (47\%) answer positively. The results show that only $55.07 \%$ of girls and $47.58 \%$ boys who are sexually active use contraception regularly. Sporadic use of contraception is recorded in $20.57 \%$ of boys and $26.09 \%$ of girls. The number of boys who never $(21.28 \%)$ or rarely $(10.64 \%)$ use contraception is higher than in girls $(24.7 \%, 9 \%$, respectively). The results indicate that girls generally have sex for love, and young men are prone to risky behavior and experimentation, since in most cases their first sexual experience is for one night. Contraception during their first intercourse is used more often by girls (75.36\%) than boys (48.94\%), but nearly half of the boys and a quarter of the girls do not use contraception or do not remember.

Table 4. Students' attitudes towards sexual intercourse

Tabela 4. Stavovi učenika prema seksualnom odnosu

\begin{tabular}{lllrr}
\hline No. Questions & Answers & Boys & Girls \\
\hline 1. & Is love necessary for having a sexual intercourse? & Yes & 52.19 & 73.24 \\
& & No & 38.60 & 16.34 \\
& & I don't know & 9.21 & 10.42 \\
\hline 2. & At the beginning of your sexual development do you feel & Yes & 52.00 & 25.00 \\
& mature enough to become sexually active? & No & 48.00 & 75.00 \\
\hline 3. & Have you had sexual intercourse? & Yes & 47.00 & 60.00 \\
& & No & 53.00 & 40.00 \\
\hline 4. & Do you use contraception? & Yes, always & 55.07 & 47.58 \\
& & Sometimes & 20.57 & 26.09 \\
& & Never & 21.28 & 7.24 \\
& Your first sexual experience? & Rarely & 20.64 & 9.00 \\
\cline { 2 - 5 } & & With a steady partner & 43.26 & 91.30 \\
& & One-night stand & 54.61 & 8.70 \\
\hline 6. & The use of contraception during the first sexual intercourse & Forced & 2.13 & - \\
\cline { 2 - 5 } & Yes & 48.94 & 75.36 \\
& & No & 31.91 & 17.39 \\
\hline
\end{tabular}


Students' views on the content of reproductive health topics in the school curriculum are presented in Table 5. The students' responses indicate that information on sexually transmitted diseases is usually disseminated through different extracurricular activities. Most students say that they are informed on these issues in extracurricular classes (52\%). Smaller number of them state that biology lessons and classes with their form teacher are a source of information while $11 \%$ of students believe that school does not offer enough information on these issues. Students' opinions are also divided considering the question "Does the school offer enough knowledge on sexual education". Slightly more than a half of the students believe that the school does not offer sufficient knowledge, while the second part of the students believe that the information they receive in schools is satisfactory. High school students largely believe that the issue of reproductive health should be taught in special courses $(37 \%)$ or in biology classes $(34 \%)$. A smaller number of students would like to learn about these topics in other classes $(10 \%)$, while a certain number of them $(19 \%)$ do not want to expand the knowledge. When asked whether the subject Sexual education should be introduced into the curriculum, more than $3 / 4$ of the students answered affirmatively.

Table 5. Students' attitudes towards the content of reproductive health in the curriculum Tabela 5. Stavovi učenika o zastupljenosti sadržaja o reproduktivnom zdravlju u nastavnom

\section{procesu}

\begin{tabular}{lllr}
\hline No. Questions & Answers & Total $\%$ \\
\hline 1. $\quad$ In which classes do you get information on & Biology class & 21.00 \\
& sexually transmitted diseases? & Extracurricular class & 52.00 \\
& & Head teacher class & 16.00 \\
& & I don't get enough information & 11.00 \\
\hline 2. & Does school offer sufficient knowledge on sexual & Yes & 46.00 \\
& education? & No & 52.00 \\
& Other & 2.00 \\
\hline 3. $\quad$ In what way would school help you increase your & More information in Biology classes & 34.00 \\
& knowledge on sexuality? & More information in all classes & 10.00 \\
& & A subject on this issue & 37.00 \\
& & I don't need more information & 19.00 \\
\hline 4. & Is it necessary to introduce the subject of Sexual & Yes & 76.00 \\
& education in the curriculum? & No & 24.00 \\
\hline
\end{tabular}

\section{Discussion}

The results presented in this paper are a summary of recent research on high school students in several municipalities of Vojvodina (Janjić-Gajšin, 2012; Vašaš, 2013; Sabo, 2013). The work is aimed at highlighting the awareness of students about the structure of the human body and physiological processes in the human body, and to show the students' attitudes regarding sexual maturation, reproductive health and sexual relationships. Since in the school year 2013/14 the subject of Sexual education has been introduced into the curriculum of particular Vojvodina high schools as an elective, the aim of the research was also to determine to what extent high school students are informed on issues related to reproductive health and whether they are interested in having a subject that addresses these issues.

The results indicate that a significant number of students lack knowledge on the structure and physiology of the human body. Students have insufficient knowledge about the human body and sexual organs, which points to inefficient teaching and acquiring of learning material. Considering the knowledge on the parts of the male reproductive system, the majority of students are able to number only the penis and testes. A considerable number of pupils do not know to specify the name of male $(37.57 \%)$ and female gamete $(22.64 \%)$. Only a small percentage of students can indicate all parts of the female reproductive system. Only about 
$64 \%$ of the respondents know that the fertile days are in mid-menstrual cycle and $40.90 \%$ of students know what ovulation is. More than half of the students also do not know how a twin pregnancy appears. Recent studies have shown that the students of vocational schools particularly lack basic knowledge on the human body and physiology of the reproductive organs, when compared to students in grammar schools and medical high schools (Vašaš, 2013). The human body is taught in the final year of primary school, however, the research suggests that a significant number of students lack the knowledge on this topic, thus implying that the present system of education does not offer sufficient information in this area. Adolescents should be provided with more information on sexual development and reproductive health, however, this is not often the case due to, among other things, an overloaded school curriculum. The results suggest that students are usually informed about reproductive health in activities outside the scope of teaching, and more than half of them are not satisfied with the amount of information they receive in school. The research has also shown that most respondents are interested in having a special subject to deal with this issue.

The survey has revealed that the main source of information for the young is the internet and their peers. This, therefore implies that the information is often one-sided, glorifying physical appearance and physical aspects of sexuality without stressing the value of emotions and measures for protecting reproductive health. Only a small percentage of respondents indicate that they talk with their parents about issues related to sexuality and reproductive health. Earlier studies of adolescents in Belgrade (Sabo, 2014) have shown that parents do not usually talk about sexuality with their children and often have a passive attitude towards the sexuality of their offspring. Adequate communication with children is important as previous studies have pointed out (Stanković, 2007) that the timely discussion of parents with children is associated with later initiation of sexual activity, fewer sexual partners and increased use of contraception. The highest percentage of the respondents most often talk about sexual issues with their friends or partners, and a lower percentage with parents or siblings, which is consistent with previous studies (Rašević, 2000; Radovanović et al., 2010). Students are interested in obtaining more information on all topics related to reproductive health. One possible way is by disseminating information and organizing youth counseling. Respondents in the highest percentage state that they would like counseling to be located at school and to work in groups with young advisers.

A significant increase in sexually transmitted infections is a consequence of risky behavior among young people. Sexually transmitted infections which occur in adolescence may have adverse effects on health in later life, especially if they do not heal in time (Sedlecki et al., 2000). When listing the venereal diseases, the majority of students can name just one disease, mostly AIDS, and a smaller percentage can name syphilis, gonorrhea, hepatitis, although some other sexually transmitted diseases like chlamydia and genital warts are more common in our population. The largest number of students know about AIDS, most likely due to the well-done campaigns; however they seem to be ignorant of other diseases which are much more common in our society. Similar results have been obtained in other studies (Sedlecki, 2001; Kapamadžija, 2002) where almost all those who were able to list a few of the sexually transmitted diseases mentioned AIDS, followed by gonorrhea and syphilis. The present results indicate that students have insufficient information regarding the ways of protection from sexually transmitted infections. Almost 33\% of students give incorrect answers, and similar findings have been recorded in studies of Kapamadžija (2002), where also most of the students mentioned condom as a way of protection against sexually transmitted diseases, while $32 \%$ of respondents gave an incorrect answer.

For most of the adolescents in this study, love is an important assumption about sexual relations, and this is especially true for girls. In the majority of cases they have their first sexual experience with a steady partner, while young men to a larger extent have the first experience with a partner for one night. Psycho-social maturity is a long and gradual process of development, which takes place much more slowly than biological maturation. The responsibility of young people to their own health is therefore often insufficient in this 
period. The results indicate that students become sexually active even though they are not mature enough, which particularly refers to girls, as the present survey reveals. Young people are today faced with the dilemma whether to accept the advice of parents and their own beliefs or opinions of their partners and peers. It is rather upsetting that only a half of the sexually active respondents use some method of contraception. In similar studies conducted in our country (Radovanović et al., 2010; Jovanović, 2009) it was also observed that less than a half of sexually active adolescent girls use modern methods of contraception. Compared with the data of other countries (Darroch et al., 2001), where contraceptive use is reported by $88 \%$ of girls in France, $92 \%$ of girls in the UK and $75 \%$ in the USA, it can be observed that young women in Serbia use contraception to a lesser extent. These data indicate that adolescents in Serbia lack awareness of the importance of contraceptive use, as well as that they ignorant of the risks that unprotected sexual intercourse carries.

\section{Conclusion}

This paper presents a summary of several transversal studies conducted in 2012 and 2013 in several municipalities in Vojvodina. The study included second, third and fourth grade grammar, medical and other vocational school students. The results have indicated that adolescent reproductive health is seriously threatened. The adolescents do not know enough about the human body and the basic physiological processes and show insufficient awareness of the importance of using contraception to preserve their reproductive health. The obtained data concerning the level of students' knowledge on sexual maturation, reproductive health and sexual relations are consistent with other previous studies in Serbia, suggesting that nothing has changed in this segment of our medical culture. Most of the students express a positive opinion of introducing a special subject into the curriculum that would deal with issues related to reproductive health. Young people are still missing a lot of information helpful for the preservation of their reproductive health. The results suggest that young people need sexual education that corresponds to their age and needs. Increasing adolescents' knowledge and developing skills that help them maintain their health is an important and necessary step in the fulfillment of their needs and rights.

Acknowledgements. We wish to thank all the students who voluntarily took part in the research without whom this study and its finding would not be possible.

\section{References}

Darroch JE, Singh S, Frost JJ. Differences in teenage pregnancy rates among five developed countries: the role of sexual activity and contraceptive use. Fam Plann Perspectives; 2001; 33:244-50.

Janjić-Gajšin S. Informisanost učenika o seksualnosti i polno prenosivim bolestima na teritoriji opštine Ruma. Master rad, Univerzitet u Novom Sadu, PMF, Departman za biologiju i ekologiju, Novi Sad; 2012.

Jovanović M.. Zdravlje mladih u Republici Srbiji, finalni izveštaj, Beograd; 2009.

Kapamadžija A. Seksualna znanja, stavovi i ponašanje adolescenata, Doktorska disertacija, Univerzitet u Novom Sadu, Medicinski fakultet, Novi Sad; 2002.

Korać-Mandić D, Novaković M. Inicijativa za reproduktivno zdravlje mladih-Finalni izveštaj, NSHC; 2008.

Radovanović S, Kocić S, Šorak M, Milić Č. Stavovi i ponašanje studenata u vezi sa reproduktivnim zdravljem. Med Pregl ; 2010; LXIII (11-12):859-862.

Rašević M. Slika mlade generacije. Sačuvajmo zdravlje, Priručnik za zdravstvene radnike o zaštiti reproduktivnog zdravlja mladih. Institut za zdravstvenu zaštitu majke i deteta Srbije Republički centar za planiranje porodice. Beograd; 2000.

Rašević M. Obrazovanje mladih za zaštitu reproduktivnog zdravlja. Zbornik instituta za pedagoška istraživanja; 2006; 38(2):472-485. 
Sabo G.. Stavovi nastavnika i učenika o zastupljenosti sadržaja o reproduktivnom zdravlju u školama opštine Subotica. Master rad, Univerzitet u Novom Sadu, PMF, Departman za biologiju i ekologiju, Novi Sad; 2013.

Sedlecki K. Značaj ispitivanja cervicitisa čiji je uzročniok Chlamydia trachomatis kod seksualno aktivnih adolescentkinja. Doktorska disertacija. Medicinski fakultet Univerziteta u Beogradu; 1999.

Sedlecki K, Banićević M, Rajin G. Reproduktivno zdravlje adolescenata. Sačuvajmo zdravlje, Priručnik za zdravstvene radnike o zaštiti reproduktivnog zdravlja mladih. Institut za zdravstvenu zaštitu majke i deteta Srbije Republički centar za planiranje porodice. Beograd; 2000.

Sedlecki K. Ponašanje i stavovi adolescenata relevantni za reproduktivno zdravlje. Stanovništvo; 2001; 39:91-117.

Stanković B.. Socijalni uticaj i reproduktivno zdravlje adolescenata. Sociološki pregled; 2007; vol XXXXI, no3:327-350.

Stefanović-Stanojević T. Socio-kulturni i emocionalni činioci rizičnog seksualnog ponašanja omladine, $\mathrm{Niš} ; 2011$.

UNICEF. Women in Transition. Regional Monitoring Reports, No 6. Florence:UNICEF International Child Development Centre; 1999.

UNICEF:Progress for children. New York:UNICEF;2012. (A report card for adolescents). Avaliable from:http://www.unicef.org/media/files/PFC2012 A report card on adolescents.pdf

Vašaš Č. Informisanost učenika o polnom sazrevanju i reproduktivnom zdravlju. Master rad, Univerzitet u Novom Sadu, PMF, Departman za biologiju i ekologiju, Novi Sad; 2013.

Vuković D, Bjegović-Mikanović V. Povezanost socijalno-ekonomskog statusa i seksualnog ponašanja adolescenata. Srpski arhiv za celokupno lekarstvo; 2007; 135(5-6):321-325.

United Nations:Commission on Population and Development.45th session. Resolution on Adolescents and Youth, 2012. Available from:http://www.un.org/esa/population/cpd/cpd2012/cpd45.htm

WHO Maternal, newborn, child and adolescent health. Available from:

http://www.who.int/maternal_child_adolescent/topics/adolescence/dev/en/

\title{
STAVOVI I ZNANJA UČENIKA SREDNJIH ŠKOLA VOJVODINE PREMA REPRODUKTIVNOM ZDRAVLJU I POLNOM SAZREVANJU
}

\author{
Tatjana Pavlica, Snježana Janjić-Gajšin, Vašaš Čila, Sabo Gabor
}

\section{Sažetak}

U periodu adolescencije mladi su izloženi različitim fiziološkim poremećajima, socijalnim bolestima i posledicama rizičnog ponašanja. Nagle promene u društvu koje dovode do povećanog siromaštva, promena vrednosti i povećanje kriminala, dovode do porasta rizičnog ponašanja mladih ljudi. Cilj istraživanja je bio da se na uzorku učenika srednjih škola u Vojvodini utvrdi kakva je njihova informisanost o ljudskom telu, fiziološkim procesima, polnom sazrevanju i reproduktivnom zdravlju. Takođe, da se utvrde stavovi učenika prema seksualnom odnosu i koliko su sadržaji o reproduktivnom zdravlju zastupljeni u nastavnom programu. U radu su korišćeni podaci nedavnih istraživanja učenika II, III i IV razreda srednjih škola, koja su sprovedena tokom 2012 i 2013. godine. Ispitani su učenici u opštinama: Ruma, Senta, Čoka, Kanjiža i Subotica. U istraživanju je primenjena metoda anketiranja. Pitanja su bila otvorenog i zatvorenog tipa, a podeljena su u četiri celine: informisanost o ljudskom telu i polnim organima, informisanje o polnom sazrevanju i reproduktivnom zdravlju, stav prema seksualnom odnosu i stavovi učenika o zastupljenosti sadržaja o reproduktivnom zdravlju u nastavnom programu. Istraživanje je ukazalo da ispitani adolescenti nemaju dovoljno znanja o ljudskom telu i osnovnim fiziološkim procesima a takođe i još uvek nedovoljno razvijenu svest o značaju upotrebe kontracepcije radi očuvanja njihovog reproduktivnog zdravlja. Većina anketiranih učenika se izjasnila da su saglasni sa uvođenjem posebnog predmeta koji bi se bavio temama vezanim za reproduktivno zdravlje. Dobijeni podaci su u skladu sa drugim ranijim istraživanjima u Srbiji, što ukazuje da se u ovom delu zdravstvene kulture ništa značajnije nije promenilo. Rezultati ukazuju da je mladima potrebno seksualno obrazovanje koje bi bilo u skladu sa njihovim uzrastom i potrebama, kako bi bili u mogućnosti da što bolje razviju životne veštine koje će im pomoći da sačuvaju svoje zdravlje.

Ključne reči: Adolescenti, učenici, reproduktivno zdravlje, polno sazrevanje, Vojvodina. 